\title{
Multiplex-PCR for simultaneous detection of 3 bacterial fish pathogens, Flavobacterium columnare, Edwardsiella ictaluri, and Aeromonas hydrophila
}

\author{
Victor S. Panangala ${ }^{1, *}$, Craig A. Shoemaker ${ }^{1}$, Vicky L. van Santen ${ }^{2}$, Kevin Dybvig $^{3}$, \\ Phillip H. Klesius ${ }^{1}$ \\ ${ }^{1}$ Aquatic Animal Health Research Unit, US Department of Agriculture, Agricultural Research Service, \\ Aquatic Animal Health Research Unit, PO Box 952, Auburn, Alabama 36831-0952, USA \\ ${ }^{2}$ Department of Pathobiology, College of Veterinary Medicine, Auburn University, Auburn, Alabama 36830, USA \\ ${ }^{3}$ Department of Genetics, University of Alabama at Birmingham, Birmingham, Alabama 35294, USA
}

\begin{abstract}
A multiplex PCR (m-PCR) method was developed for simultaneous detection of 3 important fish pathogens in warm water aquaculture. The m-PCR to amplify target DNA fragments from Flavobacterium columnare (504 bp), Edwardsiella ictaluri (407 bp) and Aeromonas hydrophila (209 bp) was optimized by adjustment of reaction buffers and a touchdown protocol. The lower detection limit for each of the 3 bacteria was 20 pg of nucleic acid template from each bacteria per m-PCR reaction mixture. The sensitivity threshold for detection of the 3 bacteria in tissues ranged between $3.4 \times$ $10^{2}$ and $2.5 \times 10^{5}$ cells g $^{-1}$ of tissue (channel catfish Ictalurus punctatus Rafinesque). The diagnostic sensitivity and specificity of the m-PCR was evaluated with 10 representative isolates of each of the 3 bacteria and 11 other Gram-negative and 2 Gram-positive bacteria that are taxonomically related or ubiquitous in the aquatic environment. Except for a single species (A. salmonicida subsp. salmonicida), each set of primers specifically amplified the target DNA of the cognate species of bacteria. $\mathrm{m}-\mathrm{PCR}$ was compared with bacteriological culture for identification of bacteria in experimentally infected fish. The m-PCR appears promising for the rapid, sensitive and simultaneous detection of Flavobacterium columnare, E. ictaluri and A. hydrophila in infected fish compared to the timeconsuming traditional bacteriological culture techniques.
\end{abstract}

KEY WORDS: Multiplex-PCR · Fish $\cdot$ Edwardsiella $\cdot$ Flavobacterium $\cdot$ Aeromonas

\section{INTRODUCTION}

Edwardsiella ictaluri, Flavobacterium columnare and Aeromonas hydrophila are 3 major bacterial pathogens of fish that cause diseases with significant economic impact on the aquaculture industry. E. ictaluri, the primary cause of enteric septicemia in channel catfish (Ictalurus punctatus Rafinesque), has also been frequently associated with disease in other food fish (Plumb \& Sanchez 1983). Flavobacterium columnare, the cause of columnaris disease, is comprised of 4 distinct genogroups (Arias et al. 2004) and has a broad host range, with known infections in over
36 species of fish throughout the world (Anderson \& Conroy 1969). A. hydrophila infects many species of fish and other terrestrial animals (Colwell et al. 1986), including humans (Janda \& Duffey 1988). Particular importance is attached to A. hydrophila from a public health perspective due to its involvement in foodborne gastroenteritis and various opportunistic infections in immunocompromised human patients (Altwegg \& Geiss 1989, Janda \& Abbott 1998, Ullmann et al. 2005).

Enteric septicemia of catfish (ESC), reported by $67 \%$ of operations within $1 \mathrm{yr}$, and columnaris disease, reported by $50 \%$ of operations within $1 \mathrm{yr}$, are the 2 
most important bacterial diseases affecting the aquaculture industry in the USA (United States Department of Agriculture 2003). The prevalence and impact of septicemic disease in fish caused by Aeromonas hydrophila (referred to as motile aeromonad septicemia, MSA), is less known. However, A. hydrophila is ubiquitous in aquatic ecosystems (Holmes et al. 1996) and recent studies have shown that catfish latently infected with A. hydrophila (carriers) could shed the organism when co-infected with Edwardsiella ictaluri (Nusbaum \& Morrison 2002). Since all 3 species of bacteria (Flavobacterium columnare, E. ictaluri, and A. hydrophila) are ubiquitous in the aquatic environment and fish are reared in extensive pond acreages with high stocking densities (20 000 to 30000 fish ha $^{-1}$ ), the occurrence of coinfections or multiple infections in the same host should not be overlooked (Jack et al. 1992). Traditional methods of diagnosing bacterial infections using culture techniques require several days to arrive at a definitive diagnosis, resulting in delayed implementation of control measures and increased potential for spreading of disease. Because PCR can target unique genetic sequences of microorganisms, PCR-based nucleic acid amplification techniques have gained recognition as rapid, sensitive, and specific methods for detection of disease-causing pathogens in various aquaculture species (Vantarakis et al. 2000, Del Cero et al. 2002, Bader et al. 2003, Bilodeau et al. 2003). When multiple bacterial pathogens are likely to occur, as in the aquatic environment, amplification of multiple target genes in a single reaction mixture is possible with the multiplex PCR (m-PCR) method (Brasher et al. 1998, Del Cero et al. 2002, Panicker et al. 2004), thus reducing cost, time and effort without compromising the test utility. In this study, we developed an m-PCR method for simultaneous identification of $F$. columnare, E. ictaluri, and A. hydrophila, 3 of the most important bacterial pathogens causing extensive losses in the channel catfish aquaculture industry.

\section{MATERIALS AND METHODS}

Bacteria isolates and culture conditions. The bacterial isolates used in this study are listed in Table 1 . The majority of the fish-pathogenic bacteria were originally isolated from diseased fish, characterized into their respective genera and species using standard methods (Arias et al. 2004, Panangala et al. 2005), and maintained in the archived culture repository of the Aquatic Animal Health Research Unit, Auburn, Alabama, USA. Additional cultures were kindly provided by John M. Grizzle (Department of Fisheries and Allied Aquaculture, Auburn University, Alabama,
USA), Andrew E. Goodwin (Department of Aquaculture/Fisheries, University of Arkansas, Pine Bluff, Arkansas, USA) and Ronald D. Schultz (Department of Pathobiology, University of Wisconsin, Madison, Wisconsin, USA). The bacterial isolates were cultured directly from glycerol stocks on brain heart infusion agar or blood agar plates (tryptic soy agar with $5 \%$ v/v defibrinated sheep blood: Difco) for Edwardsiella ictaluri and Aeromonas hydrophila, and Shieh agar (Shieh 1980) for Flavobacterium columnare. Single colonies picked after incubation for $36 \mathrm{~h}$ were transferred to $10 \mathrm{ml}$ brain heart infusion broth and cultured to log-phase growth at $28^{\circ} \mathrm{C}$ in a shaker water bath. For isolation of bacteria from tissues of experimentally infected fish, Shieh medium modified by replacing peptone with tryptone (Difco) was used for selective isolation of $F$. columnare. For isolation of E. ictaluri, Shotts selective medium (Shotts \& Waltman 1990) was used, and for isolation of A. hydrophila, blood agar plates were used. Results were recorded after 24 to $48 \mathrm{~h}$ of incubation at $28^{\circ} \mathrm{C}$. Isolates were distinguished as F. columnare, E. ictaluri and A. hydrophila on the basis of their morphological appearance on selective media and Gram-stain characteristics. Select isolates were characterized biochemically to species level using API 20E test strips (bioMerieux) and additional biochemical tests (when necessary) according to established criteria (Decostere et al. 1998, Altwegg 1999, Farmer 2003). Occasionally, contaminating organisms were also isolated on culture media, but these organisms were readily distinguished from $F$. columnare, E. ictaluri and A. hydrophila on the basis of morphological and biochemical characteristics.

Infection of fish and sample collection. Fingerling $(\sim 12$ to $14 \mathrm{~g})$ channel catfish Ictalurus punctatus Rafinesque, National Warmwater Aquaculture Center Strain 103, obtained from disease-free stock reared at the Aquatic Animal Health Research Unit, were used for experimental infection. The fish were maintained in $58 \mathrm{l}$ glass aquaria with flow-through dechlorinated tap water, constant aeration, a water temperature of $26 \pm$ $2^{\circ} \mathrm{C}$ and a $12: 12 \mathrm{~h}$ light:dark photoperiod. A commercial diet (Aquamax Grower 400 Brentwood) was fed daily to satiation. Initially, fish were randomized into 3 groups, with 7 fish per group. Fish in Group 1 were injected intraperitoneally with $0.1 \mathrm{ml}$ of a log-phase broth culture of Flavobacterium columnare ARS-1, containing $\sim 1 \times 10^{5} \mathrm{CFU} \mathrm{ml}^{-1}$, Group 2 fish were similarly injected with Edwardsiella ictaluri (American Type Culture Collection: ATCC-33202), and Group 3 fish were injected with $\sim 10^{2} \mathrm{CFU} \mathrm{ml}{ }^{-1}$ of Aeromonas hydrophila K106K. Subsequently, 3 other groups of 7 fish per group (Groups 4 to 6 ) were injected with a combination of the organisms to simulate mixed infections as follows: Group 4, F. columnare + E. ictaluri 
Table 1. Bacteria used in this study. ATCC: American Type Culture Collection; CECT: Colección Espanola de Cultivos Tipo; BRL: GIBCO, Bethesda Research Laboratories, Maryland. Isolates with prefix AL were from diseased catfish, isolated by Auburn University Fish Diagnostic Laboratory, Auburn University, Alabama; isolates with prefix ALG were provided by William Hemstreet, Alabama Fish Farming Center, Greensboro, Alabama; isolates from Mississippi were provided by David Wise, Fish Diagnostic Laboratory, Thad Cochran National Warmwater Aquaculture Center, Stoneville, Mississippi; isolates from Arkansas were provided by Andrew E. Goodwin, Department of Aquaculture, University of Arkansas at Pine Bluff, Arkansas

\begin{tabular}{|c|c|c|c|}
\hline Species & Isolate & Source & Origin \\
\hline Edwardsiella ictaluri & ATCC-33202 & Channel catfish Ictalurus punctatus Rafinesque & ATCC \\
\hline E. ictaluri & AL-93-75 & Channel catfish & Alabama \\
\hline E. ictaluri & ALG-03-58 & Channel catfish & Alabama \\
\hline E. ictaluri & ALG-03-161 & Channel catfish & Alabama \\
\hline E. ictaluri & 013-S99-1908 & Channel catfish & Mississippi \\
\hline E. ictaluri & 016-S99-1911 & Channel catfish & Mississippi \\
\hline E. ictaluri & 017-S99-1914 & Channel catfish & Mississippi \\
\hline E. ictaluri & 003-S99-1760 & Channel catfish & Mississippi \\
\hline E. ictaluri & IA-30-NJ\#1 & Tadpole madtom Noturus gyrinus Mitchell & New Jersey \\
\hline E. ictaluri & EILO & Walking catfish Clarius batrachus L. & Thailand \\
\hline Flavobacterium columnare & ATCC-23463 & Chinook salmon Oncorhynchus tshawytscha Walbaum & ATCC \\
\hline F. columnare & ARS-1 & Channel catfish & Alabama \\
\hline F. columnare & ALG-00-530 & Channel catfish & Alabama \\
\hline F. columnare & ALG-00-522 & Channel catfish & Alabama \\
\hline F. columnare & ALG-02-036 & Largemouth bass Micropterus salmoides Lacepede & Alabama \\
\hline F. columnare & BioMed & Channel catfish & Alabama \\
\hline F. columnare & HS & Channel catfish & Alabama \\
\hline F. columnare & LSU & Channel catfish & Louisiana \\
\hline F. columnare & MS-02-463 & Channel catfish & Mississippi \\
\hline F. columnare & IR & Common carp Cyprinus carpio L. & Israel \\
\hline Aeromonas hydrophila & СЕCT-839 & Milk & CECT \\
\hline A. hydrophila & CIB & Channel catfish & Alabama \\
\hline A. hydrophila & K106K & Channel catfish & Alabama \\
\hline A. hydrophila & K83B & Channel catfish & Alabama \\
\hline A. hydrophila & AL-05-58 & Channel catfish & Alabama \\
\hline A. hydrophila & AL-098-69a & Channel catfish & Alabama \\
\hline A. hydrophila & PB-04-211 & Channel catfish & Arkansas \\
\hline A. hydrophila & PB-05-269 & Largemouth bass & Arkansas \\
\hline A. hydrophila & GA-93-13 & Channel catfish & Georgia \\
\hline A. hydrophila & NC-05-02 & Channel catfish & North Carolina \\
\hline $\begin{array}{l}\text { A. salmonicida subsp. } \\
\text { salmonicida }\end{array}$ & ATCC-33658 & Atlantic salmon Salmo salar L. & ATCC \\
\hline A. sobria & ATCC-43979 & Fish (species unknown) & ATCC \\
\hline A. caviae & ATCC-15468 & Guinea Pig Cavia porcellus & ATCC \\
\hline E. tarda & AL-98-87 & Channel catfish & Alabama \\
\hline E. hoshinae & ATCC-33379 & Puffin Fratercula artica & ATCC \\
\hline F. psychrophilum & GA-05-06\#2 & Rainbow trout Oncorhynchus mykiss Walbaum & Georgia \\
\hline Vibrio anguillarium & CECT-522 & Atlantic cod Gadus morhua L. & CECT \\
\hline Yersinia rukeri & ATCC-29473 & Rainbow trout & ATCC \\
\hline Escherichia coli & $\mathrm{K}-12(\mathrm{DH} 5 \alpha)$ & Commercial & BRL \\
\hline Enterobacter sakazakii & ATCC-51329 & Human & ATCC \\
\hline Trabulsiella guamensis & ATCC- 49490 & Dust & ATCC \\
\hline Streptococcus iniae & 01-AU-HC-HSB-M2 & Striped bass Morone saxatilis Walbaum & Florida \\
\hline Streptococcus agalactiae & 19-Mullet-Br Mullet & Mugil cephalus L. & Kuwait \\
\hline
\end{tabular}

$\left(\sim 1.3 \times 10^{5} \mathrm{CFU} \mathrm{ml^{-1 }}\right.$ of each organism); Group 5, E. ictaluri + A. hydrophila $\left(\sim 1.4 \times 10^{5} \mathrm{CFU} \mathrm{ml}^{-1}\right.$ of each organism); Group 6, F. columnare + E. ictaluri $+A$. hydrophila $\left(\sim 1 \times 10^{5} \mathrm{CFU} \mathrm{ml}^{-1}\right.$ of each organism). An uninfected group (Group 7 ) of 7 fish were maintained as controls. Fish were monitored following infection and dead or moribund fish were promptly removed for sample collection. Blood was collected into $1 \mathrm{ml}$ hypo- dermic syringes by direct cardiac puncture, and the kidney and gill tissues were surgically removed. Duplicate sample sets were collected to provide for nucleic acid extraction and for bacteriological culture. In addition to samples from infected fish, tissues (gills, kidney and blood) obtained from euthanized (using $200 \mathrm{mg} \mathrm{l}^{-1}$ tricaine methanesulfonate; Western Chemical) naïve fish were spiked with $F$. columnare, $E$. 
ictaluri, and A. hydrophila in different combinations. Sterile, disposable $1 \mu \mathrm{l}$ plastic loops dipped in broth cultures containing $\sim 1 \times 10^{9} \mathrm{CFU} \mathrm{ml}^{-1}$ of bacteria were mixed vigorously with $\sim 30$ to $50 \mathrm{mg}$ of each tissue sample in $1.5 \mathrm{ml}$ microtubes and placed in an ice bath until used for bacteriological culture or nucleic acid extraction.

Nucleic acid extraction. Total nucleic acid was extracted from $200 \mu \mathrm{l}$ pure culture of each bacteria listed in Table 1, from 30 to $50 \mathrm{mg}$ tissue (blood, gills or kidney) of experimentally infected fish, and from spiked tissue samples (30 to $50 \mathrm{mg}$ ) using a High Pure PCR template preparation kit (Roche Diagnostics) according to the instructions provided. Tissues were first macerated with sterilized Kontes disposable pellet pestles (Fisher Scientific) in $10 \mu \mathrm{l}$ of buffer containing $10 \mathrm{mM}$ Tris $\mathrm{HCl}, 100 \mathrm{mM}$ EDTA, $\mathrm{pH}$ 7.6. Nucleic acid was quantified with a NanoDrop ND-1000 (NanoDrop Technologies) spectrophotometer.

Target genes, primers and optimization of $\mathbf{m}-\mathbf{P C R}$ amplification parameters. Oligonuleotide primers for genes of Flavobacterium columnare, Edwardsiella ictaluri and Aeromonas hydrophila are listed and described in Table 2. Primers targeting unique sequences within the 16S rRNA gene of E. ictaluri were designed for this study. All primers were synthesized at the Iowa State University DNA Sequencing and Synthesis Facility, Ames. Optimal conditions for the $\mathrm{m}$-PCR were empirically determined by varying template nucleic acid concentrations $(60,30$ and $20 \mathrm{ng})$, primer concentrations $(0.2$ to $0.8 \mu \mathrm{M})$, reaction buffers, and annealing temperatures. Reaction buffers tested included Master Mix (Promega) and FailSafe PCR PreMixes A-L containing $50 \mathrm{mM} \mathrm{KCl}, 200 \mu \mathrm{M}$ of each dNTP, 3 to $7 \mu \mathrm{M} \mathrm{MgCl}_{2}$ and 0 to $8 \times$ FailSafe PCRenhancer (Epicentre Biotechnologies). Annealing temperatures were adjusted between 65 and $55^{\circ} \mathrm{C}$ and a touchdown PCR protocol (Don et al. 1991) was employed with the primer annealing temperature decreased by $0.3^{\circ} \mathrm{C}$ per cycle, from 63 to $54^{\circ} \mathrm{C}$, for 30 cycles. Based on the results, the final m-PCR mixture $(25 \mu l)$ contained $12.5 \mu \mathrm{l} 1 \times$ Epicenter FailSafe PreMix Buffer-D, $1 \mu \mathrm{l}(5 \mathrm{U})$ Taq DNA polymerase (Promega), $1 \mu \mathrm{l}(20 \mathrm{ng})$ sample nucleic acid template, $3 \mu \mathrm{l}$ sterile distilled water, and the following concentrations of primers: $0.6 \mu \mathrm{M}$ each of $\mathrm{FcF}_{\mathrm{C}} / \mathrm{FcRs}_{\mathrm{c}}, 0.4 \mu \mathrm{M}$ each of EiFd-1/EiRs-1, and $0.5 \mu \mathrm{M}$ each of AeroFd/AeroRs. The cycling parameters consisted of an initial denaturation at $95^{\circ} \mathrm{C}$ for $4 \mathrm{~min}$, followed by 30 cycles of denaturation $95^{\circ} \mathrm{C}$ for $30 \mathrm{~s}$, annealing at 63 to $54^{\circ} \mathrm{C}$ (decreased by $0.3^{\circ} \mathrm{C}$ each cycle) for $45 \mathrm{~s}$, extension at $72^{\circ} \mathrm{C}$ for $30 \mathrm{~s}$ and a final extension at $72^{\circ} \mathrm{C}$ for $10 \mathrm{~min}$. A negative control (no template DNA) and positive controls (purified DNA from each of $F$. columnare, $E$. ictaluri and A. hydrophila) were included in each batch of reactions. Amplification was performed in a Tgradient thermocycler (Whatman Biometra) and PCR products were analyzed by electrophoresis on $3 \%$ agarose gels (3:1 Nu-Sieve agarose, Cambrex Bio Science) at $5 \mathrm{~V} \mathrm{~cm}^{-1}$. Gels were stained in the dark with 1× SYBR-Green-1 nucleic acid stain (Molecular Probes) and scanned and documented with a Kodak Gel Logic 440 system (Eastman Kodak).

Sensitivity and specificity of m-PCR. Analytical sensitivity of the m-PCR was assessed with nucleic acid from pure cultures of Flavobacterium columnare ALG00-530, Edwardsiella ictaluri AL-93-75 and Aeromonas hydrophila K106K. Each template was standardized to

Table 2. Primer sequences, locations and predicted sizes of amplified products of target DNA, showing gene and GenBank Accession Nos. of sequences from which primer sequences were derived. Location: location within sequence; Size: size of amplified product

\begin{tabular}{|c|c|c|c|c|c|}
\hline Primer & Oligonucleotide sequence $\left(5^{\prime}-3^{\prime}\right)$ & Accession No. & Location & Size (bp) & Source \\
\hline \multicolumn{6}{|c|}{ Flavobacterium columnare } \\
\hline FcFd (forward) & TGCGGCTGGATCACCTCCTTTCTAGAGACA & 16S-23S rRNA & $1-30$ & \multirow[t]{2}{*}{504} & \multirow[t]{2}{*}{ Welker et al. (2005) } \\
\hline FcRs (reverse) & TAATYRCTAAAGATGTTCTTTCTACTTGTTTG & $\begin{array}{l}\text { intergenic spacer } \\
\text { region AY754370 }\end{array}$ & $474-505$ & & \\
\hline \multicolumn{6}{|l|}{ Edwardsiella ictaluri } \\
\hline EiFd-1 (forward) & GTAGCAGGGAGAAAGCTTGC & 16S rRNA & $183-202$ & \multirow{2}{*}{407} & \multirow{2}{*}{ This study } \\
\hline EiRs-1 (reverse) & GAACGCTATTAACGCTCACACC & AF310622 & $569-590$ & & \\
\hline \multicolumn{6}{|c|}{ Aeromonas hydrophila } \\
\hline AeroFd (forward) & CCAAGGGGTCTGTGGCGACA & Aerolysin & $645-664$ & \multirow[t]{2}{*}{209} & \multirow[t]{2}{*}{ Pollard et al. (1990) } \\
\hline AeroRs (reverse) & TTTCACCGGTAACAGGATTG & M16495 & $834-853$ & & \\
\hline \multicolumn{6}{|l|}{ Universal bacterial } \\
\hline fD1 (forward) & ccgaattcgtcgacaacAGAGTTTGATCCTGGCTCAG & 16S rRNA & $1525-1544$ & \multirow[t]{2}{*}{1504} & \multirow[t]{2}{*}{ Weisburg et al. (1991) } \\
\hline rP1 (reverse) & cccgggatccaagcttACGGTTACCTTGTTACGACTT ${ }^{\mathrm{b}}$ & J01695 & $3009-3029$ & & \\
\hline
\end{tabular}


contain $20 \mathrm{ng} \mu^{-1}$ of nucleic acid. The nucleic acid was 10 -fold serially diluted down to $2 \mathrm{fg} \mathrm{l}^{-1}$ and $1 \mu \mathrm{l}$ of each dilution used as template in the m-PCR assay described. To determine the sensitivity in mixed culture, initial pure cultures of each bacterium ( $F$. columnare, E. ictaluri and A. hydrophila) at log-phase growth were 10-fold diluted 4 times and then 2-fold serially diluted in PBS pH 7.2. Corresponding dilutions of each bacterial species were mixed. Total nucleic acid was extracted from $200 \mu$ l of each mixture and $1 \mu l$ subjected to m-PCR as described above.

For additional analytical sensitivity assessment, tissues (blood, gills and kidney) from naïve fish were spiked with serial dilutions of log-phase cultures of the 3 bacteria Flavobacterium columnare, Edwardsiella ictaluri and Aeromonas hydrophila. The concentration of log-phase cultures was first adjusted to optical densities (OD) at $540 \mathrm{~nm}$ of 0.7 for F. columnare and 1.0 for E. ictaluri and $A$. hydrophila. These dilutions were determined to contain $1.6 \times 10^{9} \mathrm{CFU} \mathrm{ml}^{-1} \mathrm{~F}$. columnare, $3.5 \times 10^{9} \mathrm{CFU} \mathrm{m}{ }^{-1}$ E. ictaluri, and $2.5 \times 10^{9} \mathrm{CFU} \mathrm{ml}^{-1}$ A. hydrophila. One hundred microliters of each bacterial dilution was mixed with $100 \mu$ l of tissue (blood) or tissue homogenate (gills or kidney) and total nucleic acid prepared from the mixture using guanidinium thiocyanate acid as previously described (Casas et al. 1995); $1 \mu \mathrm{l}$ of the $10 \mu \mathrm{l}$ of isolated nucleic acid from each sample was used in the m-PCR reaction mixture.

Diagnostic sensitivity of each primer set for its target species was assessed by PCR amplification of nucleic acid extracted from pure cultures of 10 isolates of each species (Flavobacterium columnare, Edwardsiella ictaluri and Aeromonas hydrophila). Template nucleic acids from 1 isolate of each species of bacteria were also amplified together in each possible combination.
Additionally, nucleic acid extracted from 11 Gramnegative bacteria listed in Table 1, which are either taxonomically related or ubiquitous in the aquatic environment and 2 Gram-positive bacteria (Streptococcus iniae and $S$. agalactiae) previously isolated from diseased fish (bass or mullet) were tested in the $\mathrm{m}-\mathrm{PCR}$ to confirm diagnostic specificity.

\section{RESULTS}

\section{Optimization of the m-PCR and cycling parameters}

The m-PCR amplification of all 3 target gene segments yielding comparable band intensities was achieved with the Epicentre FailSafe PreMix Buffer-D and $1 \mu \mathrm{l}$ (5 U) of Taq DNA polymerase (Promega). Adjusting the cycling parameters to include the stepwise reduction of the annealing temperature from 63 to $54^{\circ} \mathrm{C}$ considerably improved the amplification of the 3 target gene segments and eliminated spurious bands (Fig. 1). Additionally, resolving the amplified products on 3:1 Nu-Sieve agarose (compared to LE-agarose) and staining the gel with SYBR-Green-1 nucleic acid stain (compared to ethidium bromide), improved the sharpness and intensity of the resolved bands.

\section{Diagnostic sensitivity and specificity of $\mathbf{m}-\mathrm{PCR}$}

The diagnostic sensitivity and specificity of the m-PCR was evaluated by testing purified nucleic acid templates prepared from 10 isolates representing each of the species Flavobacterium columnare, Edwardsiella ictaluri and Aeromonas hydrophila and several other

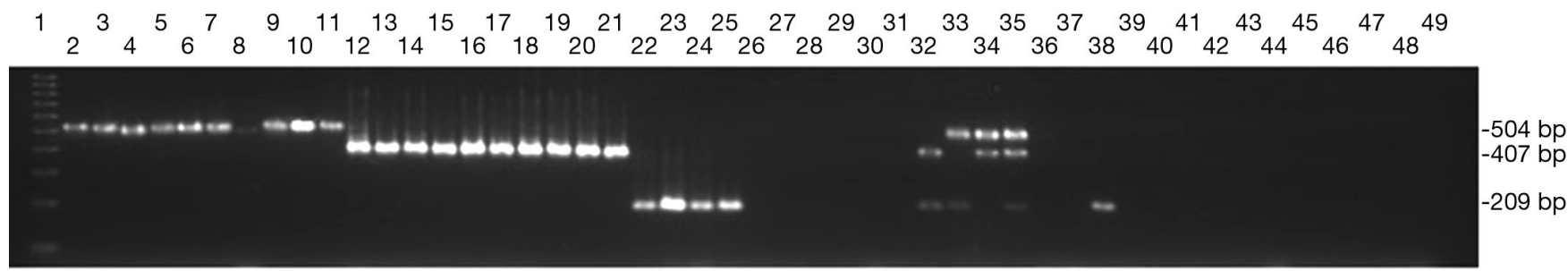

Fig. 1. Flavobacterium columnare, Edwardsiella ictaluri and Aeromonas hydrophila multiplex-PCR (m-PCR) amplified products resolved by agarose gel electrophoresis showing diagnostic sensitivity. Lane 1: 100 bp DNA ladder (Cambrex). Lanes 2 to 11: Templates isolated from $F$. columnare isolates; 2, ATCC-23463; 3, ARS-1; 4, ALG-00-530; 5, ALG-00-522; 6, ALG-02-036; 7, BioMed; 8, LSU; 9, MS-02-463; 10, HS; 11, IR. Lanes 12 to 21: E. ictaluri isolates; 12, ATCC-33202; 13, AL-93-75; 14, ALG-03-58; 15, ALG-03-161; 16, 013-S99-1908; 17, 016-S99-1911; 18, 017-S99-1914; 19, 003-S99-1760; 20, IA-30-NJ\#1; 21, EILO. Lanes 22 to 31: A. hydrophila isolates; 22, CECT-839; 23, K106K; 24, PB-05-269; 25, GA-93-13; 26, K83B; 27, AL-05-58; 28, AL-098-69a; 29, CIB; 30, NC-05-02; 31, PB-04-211. (A. hydrophila isolates tested in Lanes 22 to 25 are aerolysin-positive, those in Lanes 26 to 31 aerolysin-negative). Lane 32: amplicons from mixture of E. ictaluri and A. hydrophila; Lane 33: amplicons from mixture of $F$. columnare and A. hydrophila; Lane 34: amplicons from mixture of F. columnare and E. ictaluri; Lane 35: amplicons from mixture of F. columnare, E. ictaluri and A. hydrophila; Lane 36: A. sobria (ATCC-43979); Lane 37: A. caviae (ATCC-15468); Lane 38: A. salmonicida (ATCC-33658); Lane 39: Edwardsiella tarda (AL-98-87); Lane 40: E. hoshinae (ATCC-33379); Lane 41: F. psychrophilum (GA-05-06\#2); Lane 42: Vibrio anguillarium (CECT-522); Lane 43: Yersinia ruckeri (ATCC-29473); Lane 44: Escherichia coli, K-12 (DH5 $\alpha$ ); Lane 45: Enterobacter sakazakii (ATCC-51329); Lane 46: Trabulsiella guamensis (ATCC-49490); Lane 47: Streptococcus iniae (01-AU-HC-HSB-M2); Lane 48: S. agalactiae (19-Mullet-Br); Lane 49: no template negative-control 


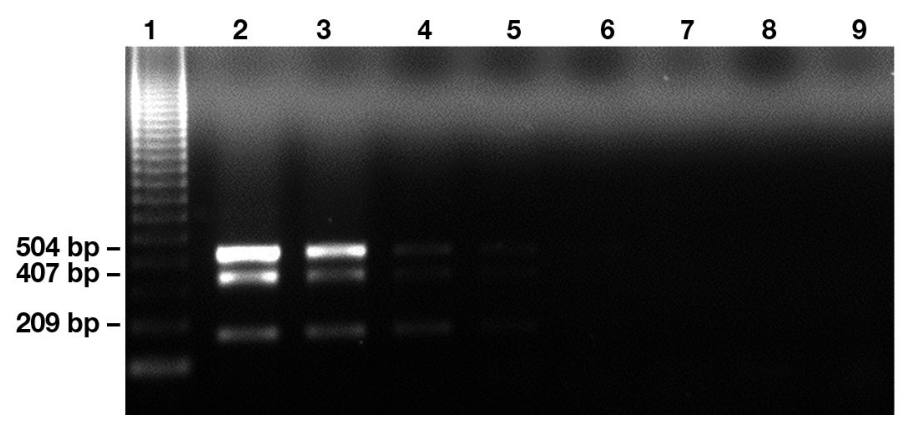

Fig. 2. Flavobacterium columnare, Edwardsiella ictaluri and Aeromonas hydrophila multiplex-PCR amplified products resolved by agarose gel electrophoresis showing the lowest level of detection of target nucleic acid from F. columnare, E. ictaluri and A. hydrophila. Lane 1: 123 bp DNA ladder (Invitrogen) as size standard. Amplicons generated = Lane 2: $20 \mathrm{ng}$ of each template; Lane 3: 2 ng of each template; Lane 4: $200 \mathrm{pg}$ of each template; Lane 5: $20 \mathrm{pg}$ of each template; Lane 6: $2 \mathrm{pg}$ of each template; Lane 7: $200 \mathrm{fg}$ of each template; Lane 8: $20 \mathrm{fg}$ of each template; Lane 9: $2 \mathrm{fg}$ of each template. $504 \mathrm{bp}$ amplicon amplified from $F$. columnare DNA, $407 \mathrm{bp}$ amplicon from E. ictaluri DNA, and $209 \mathrm{bp}$ amplicon from A. hydrophila DNA

bacteria phylogenetically related or commonly occurring in the aquatic environment (Table 1). Speciesspecific amplicons of the predicted sizes were observed for all isolates of $F$. columnare (504 bp), $E$. ictaluri $(407 \mathrm{bp})$ and aerolysin-positive strains of $A$. hydrophila (209 bp) (Fig. 1). Amplification of the target DNA sequences of all 3 bacterial species yielded comparable band intensities. With the exception of $A$. salmonicida subsp. salmonicida, which produced a $209 \mathrm{bp}$ amplification product with the primers specific for the aerolysin gene, all other bacteria (other than the 3 targeted bacterial species) were found to be negative by m-PCR (Fig. 1). An amplification product using the set of universal bacterial primers as a positive control confirmed the presence of amplifiable bacterial DNA in the m-PCR negative samples.

\section{Analytical sensitivity of m-PCR}

The lowest limit of detection of the m-PCR amplified DNA from each of the targeted species was $20 \mathrm{pg}$ nucleic acid template (Fig. 2). The detection limits for bacterial cells, determined by mixing dilutions of pure cultures, isolating nucleic acids, and using the nucleic acids as template for $\mathrm{m}-\mathrm{PCR}$, were 50 to 25 cells for Flavobacterium columnare, 28 to 14 cells for Edwardsiella ictaluri and 1300 to 650 cells for Aeromonas hydrophila (Fig. 3). To determine the sensitivity of the m-PCR for detection of bacteria in tissues, 10-fold serial dilutions of each bacterial species (F. columnare, E. ictaluri and $A$. hydrophila) were added to tissue homogenates from naïve fish. DNA isolated from these spiked homogenates was used as template for m-PCR. The detection limits for each bacterial species in $1 \mathrm{~g}$ of each tissue ranged from $3.4 \times 10^{2}$ to $2.5 \times 10^{5}$ cells g $^{-1}$ tissue (Table 3). Differences in sensitivity varied among tissues and bacterial species. However, detection limits in blood were lower than or the same as in the 2 other tissues for all species.

\section{Comparison of detection of bacteria in tissue sam- ples by m-PCR and bacteriological culture}

Bacteriological culture and m-PCR test results on the tissues from experimentally infected catfish are compared in Table 4. Each of the Groups 1, 2 and 3 that were infected with a single species of bacteria (Flavobacterium columnare, Edwardsiella ictaluri, or Aeromonas hydrophila) produced predicted size amplicons corresponding to the specific target bacterial DNA. With a few exceptions, the majority of tissues gave positive m-PCR results in agreement with bacteriological culture (Table 4). Bacteriological culture and $\mathrm{m}-\mathrm{PCR}$ revealed the presence of indigenous $A$. hy-

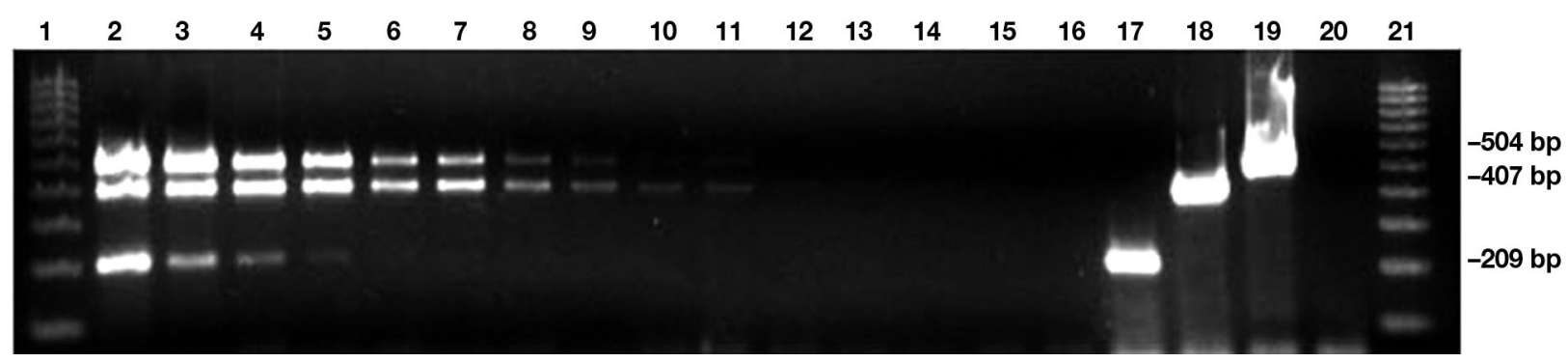

Fig. 3. Flavobacterium columnare, Edwardsiella ictaluri and Aeromonas hydrophila multiplex-PCR products resolved by agarose gel electrophoresis showing sensitivity of detection of F. columnare, E. ictaluri and A. hydrophila in mixtures of pure-culture bacterial suspensions of the 3 bacteria. Lane 1: $100 \mathrm{bp}$ DNA ladder; Lanes 2 to 16: Templates prepared from mixtures containing $F$. columnare $\left(1.6 \times 10^{6}, 1.6 \times 10^{5}, 1.6 \times 10^{4}, 1.6 \times 10^{3}, 800,400,200,100,50,25,13,7,4,2,1 \mathrm{cells} \mathrm{ml}^{-1}\right)$, E. ictaluri $\left(3.5 \times 10^{6}, 3.5 \times 10^{5}\right.$, $3.5 \times 10^{4}, 3.5 \times 10^{3}, 1750,875,437,219,110,55,28,14,7,4,2$ cells ml $\left.^{-1}\right)$, A. hydrophila $\left(2.6 \times 10^{6}, 2.6 \times 10^{5}, 2.6 \times 10^{4}, 2.6 \times 10^{3}, 1300\right.$, $650,325,163,82,41,21,11,6,3,2$ cells ml $^{-1)}$. Lanes 17 to 19: template DNA from A. hydrophila, E. ictaluri and F. columnare, respectively (positive controls); Lane 20: no template (negative control); Lane 21: 100 bp DNA ladder 
Table 3. Detection limit (cells $\mathrm{g}^{-1}$ tissue) of m-PCR in catfish Ictalurus punctatus tissue samples spiked with bacteria Flavobacterium columnare, Edwardsiella ictaluri, and Aeromonas hydrophila

\begin{tabular}{|lccc|}
\hline \multirow{2}{*}{ Bacteria } & \multicolumn{3}{c|}{ Tissue } \\
\cline { 2 - 4 } & Blood & Gills & Kidney \\
\hline F. columnare & $1.6 \times 10^{3}$ & $1.6 \times 10^{3}$ & $1.6 \times 10^{3}$ \\
E. ictaluri & $3.4 \times 10^{2}$ & $3.4 \times 10^{3}$ & $3.4 \times 10^{4}$ \\
A.hydrophila & $2.5 \times 10^{4}$ & $2.5 \times 10^{4}$ & $2.5 \times 10^{5}$ \\
\hline
\end{tabular}

drophila in 4 of the 7 fish that were infected with a combination of F. columnare and E. ictaluri (Group 4), in addition to the 2 organisms with which they were experimentally infected (Table 4). When tissue samples from nearly all fish that were infected with a mixture of bacteria containing A. hydrophila (Groups 5 and 6) were cultured, overgrowth of the cultures by A. hydrophila prevented the detection of $F$. columnare and sometimes of E. ictaluri by bacteriological culture. However, F. columnare and/or E. ictaluri were detected in these samples by m-PCR. Some variation in the fragment intensity was observed when the m-PCR amplified products were resolved by agarose gel electrophoresis. This may be due to the low copy-number of target DNA in some of the samples compared to others. Reduced fragment intensities were particularly evident in bacterial DNA extracted from blood and gill samples compared to the kidney samples where the density of bacteria was relatively high. For kidney samples the sensitivity of m-PCR was equal to or greater than bacteriological culture. The tissues collected from uninfected control fish were negative for $F$. columnare, E. ictaluri and $A$. hydrophila by both culture and m-PCR (Table 4).

All tissues spiked with pure cultures of Flavobacterium columnare, Edwardsiella ictaluri and Aeromonas hydrophila (in different combinations) yielded the predicted size amplicons of the homologous bacteria with relatively equal intensities. Results are compared with bacteriological culture results in Table 5. With the exception of failure to detect $F$. columnare by bacteriological culture in tissues spiked with all 3 bacteria due to overgrowth of cultures with A. hydrophila, results of $\mathrm{m}-\mathrm{PCR}$ were in agreement with bacteriological culture results.

\section{DISCUSSION}

The 3 species of bacteria Flavobacterium columnare, Edwardsiella ictaluri and Aeromonas hydrophila are

Table 4. Catfish Ictalurus punctatus experimentally infected with Flavobacterium columnare (FC), Edwardsiella ictaluri (EI), and Aeromonas hydrophila $(A H)$. Bacteriological culture and m-PCR results for catfish tissues. n: no. of catfish examined

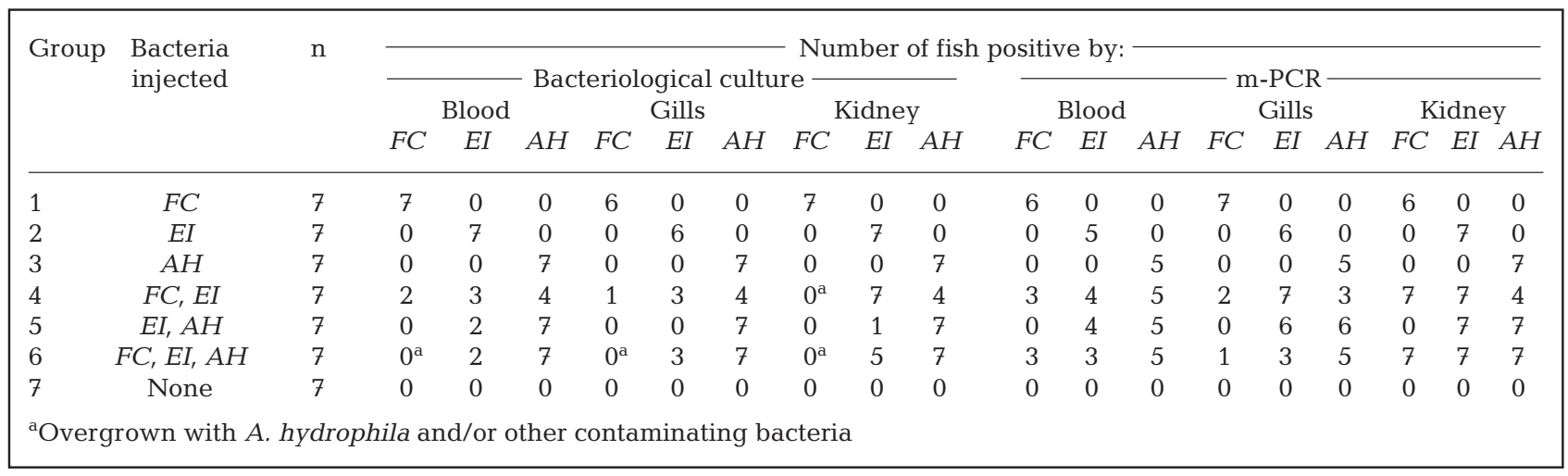

Table 5. Bacteriological culture and m-PCR results for non-infected catfish Ictalurus punctatus tissue samples spiked with mixtures of bacteria Flavobacterium columnare $(F C)$, Edwardsiella ictaluri (EI), and Aeromonas hydrophila (AH). n: no. of catfish examined

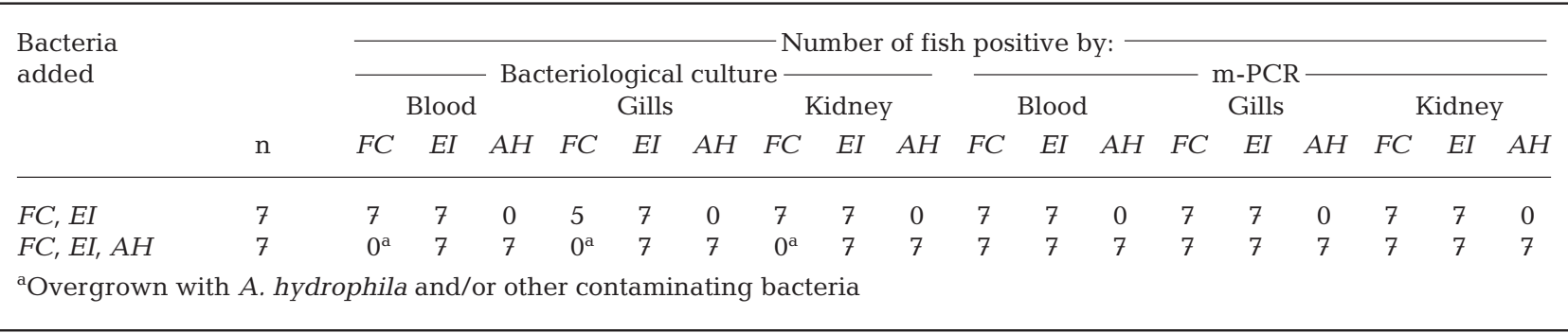


ubiquitous in the aquatic environment and the possibility of dual infections is likely (Hawke \& Khoo 2004). Our detection of $A$. hydrophila in catfish Ictalurus punctatus injected with $F$. columnaris and E. ictaluri corroborate findings of others that infection with $E$. ictaluri elicits shedding of previously inapparent $A$. hydrophila (Nusbaum \& Morrison 2002). In most instances, little more than anecdotal experience with mixed infections is available (Wagner et al. 2002). Thus, the need for increased awareness of mixed infections and rapid diagnosis of disease in food fish caused by these 3 important bacterial pathogens, prompted us to develop a multiplex-PCR.

In this study, 3 sets of primers, each specific for a conserved gene segment of the cognate bacterial species, were used for simultaneous detection of Flavobacterium columnare, Edwardsiella ictaluri and Aeromonas hydrophila. We designed oligonucleotide primers corresponding to short unique segments within the E. ictaluri 16S rRNA gene. Recent analysis of the 16S-23S intergenic spacer regions of the rRNA operons in E. ictaluri has revealed that this genospecies represents a coherent homogeneous cluster within the family Enterobacteriaceae (Panangala et al. 2005). Amplification using our primers specific for the E. ictaluri 16S rRNA gene generated a 407 bp product from 10 archived $E$. ictaluri isolates from different geographic locations.

For identification of Flavobacterium columnare, we used primers that were specific for a region of the $16 \mathrm{~S}-23 \mathrm{~S}$ intergenic spacer region of $F$. columnare that had been previously designed and used by Welker et al. (2005). In contrast to Edwardsiella ictaluri, several studies have indicated distinctive genotypic diversity among F. columnare isolates (Triyanto \& Wakabayashi 1999, Arias et al. 2004). Despite the genetic polymorphism, primers designed by Welker et al. (2005) were able to amplify DNA from all $F$. columnare fish isolates included in the study by Arias et al. (2004) and the $10 F$. columnare isolates when used in the m-PCR assay in this study.

As with Flavobacterium and Edwardsiella, members of the genus Aeromonas are autochthonous to freshwater aquatic ecosystems world-wide and can survive over a wide range of temperatures (Altwegg \& Geiss 1989). A great deal of confusion and controversy has prevailed over the taxonomic classification of Aeromonas species due to the lack of precise biochemical and/or other phenotypic properties and inadequacy of reliable typing schemes (Kaznowski 1998, Abbott et al. 2003). On the basis of $16 \mathrm{~S}$ rDNA sequencing, all species of the genus Aeromonas are presently included under a distinct family, Aeromonadaceae. Most, if not all, fish-pathogenic A. hydrophila produce a cytolytic toxin aerolysin. The primer pairs previously designed for PCR amplification of a portion of the aerolysin gene (Pollard et al. 1990) were used in the m-PCR. These primers were originally designed to avoid regions of homology in the structural genes for A. sobria aerolysin, Escherichia coli hemolysin A, and/or Staphylococcus aureus $\alpha$-toxin (Lior \& Johnson 1991). The primers target a $209 \mathrm{bp}$ fragment of the aerolysin gene, which was present in all aerolysin-positive fish isolates of $A$. hydrophila used in this study.

The diagnostic sensitivity and specificity of the mPCR assay was evaluated by testing nucleic acid prepared from 10 biochemically characterized strains of each of the bacterial species Flavobacterium columnare, Edwardsiella ictaluri and Aeromonas hydrophila and from 13 other bacterial species that are phylogenetically related or frequently isolated from fish. Positive m-PCR amplification of the targeted DNA templates from each of the bacteria with predicted-size amplicons indicated that the test identified various isolates of the respective microbial pathogens. As expected, A. hydrophila isolates lacking aerolysin were negative in the $\mathrm{m}$-PCR assay. With the exception of A. salmonicida subsp. salmonicida, no DNA amplification was observed with any of the other bacteria included in this study. However, amplification of $A$. salmonicida subsp. salmonicida DNA is relatively inconsequential to the diagnosis of bacterial infections in warm-water-cultured food fish species because typical A. salmonicida subsp. salmonicida is psychrophilic, has not been isolated from warm water cultured food fish species such as channel catfish or tilapia, and is largely a pathogen of salmonids (Dalsgaard et al. 1994).

PCR techniques have previously been developed for identification of each of the 3 bacterial species (Pollard et al. 1990, Bader et al. 2003, Bilodeau et al. 2003). All of these studies used PCR amplification of a single targeted gene segment of a given bacterium with a single set of primers. In the m-PCR, where several sets of primers are used in the reaction for amplification of multiple target genes, the diagnostic sensitivity or detection limit is generally considered to be low (Rosenfield \& Jaykus 1999, Jean et al. 2004, Lee et al. 2005). In at least 1 study, a 10-fold decrease in detection sensitivity compared to single PCR was recorded (Jean et al. 2004). In an m-PCR-based method for simultaneous detection of 4 pathogens involved in warm-water streptococcosis in fish tissues, Mata et al. (2004) recorded detection limits of $5 \times 10^{3}$ cells g $^{-1}$ of

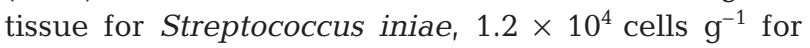
S. difficilis, $1 \times 10^{4}$ cells g ${ }^{-1}$ for $S$. paraubiris, and $2.5 \times$ $10^{3}$ cells $\mathrm{g}^{-1}$ for Lactococcus garviae. In the present study, the m-PCR diagnostic sensitivity threshold for detection of the 3 bacteria in tissues was comparable to that obtained by Mata et al. (2004). 
The m-PCR was $100 \%$ sensitive for detecting representative isolates of Flavobacterium columnare, Edwardsiella ictaluri, and the aerolysin toxin-producing Aeromonas hydrophila. Tissue samples spiked with approximately equal concentrations of the 3 bacteria tested positive for E. ictaluri and A. hydrophila by bacterial culture but were consistently culture-negative for $F$. columnare. In contrast, similarly treated tissue samples tested positive for all 3 species of bacteria with the $\mathrm{m}-\mathrm{PCR}$. The ability to detect specific bacteria by $\mathrm{m}-$ PCR, in culture-negative samples has been reported previously (Corless et al. 2001, Richtzenhain et al. 2002). A likely explanation for inability of bacterial culture to detect $F$. columnare in mixed infections is outcompetition by $A$. hydrophila. It has been documented that $A$. hydrophila suppresses the growth of $F$. columnare (Chowdhury \& Wakabayashi 1989). In the present study we found that $A$. hydrophila outcompetes not only F. columnare but also E. ictaluri. These findings provide a compelling reason for employing the m-PCR as a diagnostic testing strategy when dual and/or multiple infections are suspected. Thus the mPCR offers a rapid and reliable procedure for detection of infection and for implementing prompt measures to prevent the spread of disease from pond to pond or to neighboring farms.

Acknowledgements. This work was supported by the US Department of Agriculture, Agricultural Research Service, Current Research Information Systems Project No. 642032000-022-00D. The authors gratefully acknowledge the technical assistance of Ryan Wood and Mrs. Paige Mumma and the management team of the Aquatic Animal Health Research Unit, aquatic facility for daily care and monitoring of the catfish. This research was conducted in compliance with all relevant federal guidelines and institutional policies. Mention of trade names or commercial products in this publication is solely for the purpose of providing specific information and does not imply recommendation or endorsement by the US Department of Agriculture.

\section{LITERATURE CITED}

Abbott SL, Cheung WKW, Janda JM (2003) The genus Aeromonas: biochemical characteristics, atypical reactions, and phenotypic identification shemes. J Clin Microbiol 41:2348-2357

Altwegg M (1999) Aeromonas and Plesiomonas. In: Murray PR, Baron EJ, Pfaller MA, Tenover FC, Yolken RH (eds) Manual of clinical microbiology, 7th. edn. American Society for Microbiology Press, Washington DC, p 507-516

Altwegg M, Geiss HK (1989) Aeromonas as a human pathogen. Crit Rev Microbiol 16:253-286

Anderson JIW, Conroy DA (1969) The pathogenic Myxobacteria with special reference to fish disease. J Appl Bacteriol 32:30-39

Arias CR, Welker TL, Shoemaker CA, Abernathy JW, Klesius $\mathrm{PH}$ (2004) Genetic fingerprinting of Flavobacterium columnare isolates from cultured fish. J Appl Microbiol 97:
$421-428$

Bader JA, Shoemaker CA, Klesius PH (2003) Rapid detection of columnaris disease in channel catfish (Ictalurus punctatus) with a new species-specific $16 \mathrm{~S}$ rRNA gene-based PCR primer for Flavobacterium columnare. J Microbiol Methods 52:209-220

Bilodeau AL, Waldbieser GC, Terhune JS, Wise DJ, Wolters WR (2003) A real time polymerase chain reaction assay of the bacterium Edwardsiella ictaluri in channel catfish. J Aquat Anim Health 15:80-86

Brasher CW, De Paola A, Jones DD, Bej AK (1998) Detection of microbial pathogens in shellfish with multiplex PCR. Curr Microbiol 37:101-107

Casas I, Powell L, Klapper PE, Cleator GM (1995) New method for the extraction of viral RNA and DNA from cerebrospinal fluid for use in polymerase chain reaction assay. J Virol Methods 53:25-36

Chowdhury MBR, Wakabayashi H (1989) Effects of competitive bacteria on the survival and infectivity of Flexibacter columnaris. Fish Pathol 24:9-15

Colwell RR, MacDonell MR, DeLey J (1986) Proposal to recognize the family Aeromonadaceae fam. nov. Int J Syst Bacteriol 36:473-477

Corless CE, Guiver M, Borrow R, Edwards-Jones V, Fox AJ, Kaczmarski EB (2001) Simultaneous detection of Neisseria meningitides, Haemophilus influenzae, and Streptococcus pneumoniae in suspected cases of meningitis and septicemia using real-time PCR. J Clin Microbiol 39: $1553-1558$

Dalsgaard I, Nielsen B, Larsen JL (1994) Characterization of Aeromonas salmonicida subsp. salmonicida: a comparative study of strains of different geographic origin. J Appl Bacteriol 77:21-30

Decostere A, Haesebrouck F, Devries LA (1998) Characterization of 4 Flavobacterium columnare (Flexibacter columnaris) strains isolated from tropical fish. Vet Microbiol 62: $35-45$

Del Cero A, Marquez I, Guijarro JA (2002) Simultaneous detection of Aeromonas salmonicida, Flavobacterium psychrophilum and Yersinia ruckeri, 3 major fish pathogens by multiplex PCR. Appl Environ Microbiol 68:5177-5180

Don RH, Cox PT, Wainwright BJ, Baker K, Mattick JS (1991) 'Touchdown' PCR to circumvent spurious priming during gene amplification. Nucleic Acids Res 19:4008

Farmer JJ III (2003) Enterobacteriaceae: introduction and identification. In: Murray PR, Baron EJ, Jorgensen JH, Pfaller MA, Yolken RH (eds) Manual of clinical microbiology, 8th edn. American Society for Microbiology Press, Washington DC, p 636-653

Hawke JP, Khoo LH (2004) Infectious diseases. In: Tucker CS, Hargreaves JA (eds) Biology and culture of channel catfish. Elsevier, San Diego, CA, p 387-433

Holmes P, Niccolls M, Sartory D (1996) The ecology of mesophilic Aeromonas in the aquatic environment. In: Austin B, Altwegg M, Gosling PJ, Joseph S (eds) The genus Aeromonas. John Wiley \& Sons, Chichester, p $127-150$

Jack SW, Taylor PW, Crosby MD, Freund J, MacMillan JR, Durborrow RM (1992) Summary of bacterial isolates from farm-reared channel catfish (1979-1988). J Vet Diagn Investig 4:193-195

Janda JM, Abbott SL (1998) Evolving concepts regarding the genus Aeromonas: an expanding panorama of species, disease presentation, and unanswered questions. Clin Infect Dis 27:332-344

Janda JM, Duffey PS (1988) Mesophilic aeromonads in human disease: current taxonomy, laboratory identifica- 
tion, and infectious disease spectrum. Rev Infect Dis 10: 980-997

Jean J, D'Souza DH, Jaykus LA (2004) Multiplex nucleic acid sequence-based amplification for simultaneous detection of several enteric viruses in model ready-to-eat foods. Appl Environ Microbiol 70:6603-6610

Kaznowski A (1998) Identification of Aeromonas strains of different origin to genomic species level. J Appl Microbiol 84:423-430

Lee MA, Wang D, Yap EH (2005) Detection and differentiation of Burkholderia pseudomallei, Burkholderia mallei, and Burkholderia thailandensis by multiplex PCR. FEMS Immunol Med Microbiol 43:413-417

Lior H, Johnson WM (1991) Application of the polymerase chain reaction (PCR) to detection of the aerolysin gene in whole cell cultures of $\beta$-hemolytic Aeromonas hydrophila. Experientia 47:421-424

Mata AI, Gibello A, Casamayor A, Blanco MM, Dominguez L, Fernandez-Garayzabal JF (2004) Multiplex PCR assay for detection of bacterial pathogens associated with warmwater Streptococcosis in fish. Appl Environ Microbiol 70: 3183-3187

Nusbaum KE, Morrison EE (2002) Edwardsiella ictaluri bacteraemia elicits shedding of Aeromonas hydrophila complex in latently infected channel catfish, Ictalurus punctatus (Rafinesque). J Fish Dis 25:343-350

Panangala VS, van Santen VL, Shoemaker CA, Klesius PH (2005) Analysis of 16S-23S intergenic spacer regions of the rRNA operons in Edwardsiella ictaluri and Edwardsiella tarda isolates from fish. J Appl Microbiol 99:657-669

Panicker G, Vickery MCL, Bej AK (2004) Multiplex PCR detection of clinical and environmental strains of Vibrio vulnificus in shellfish. Can J Microbiol 50:911-922

Plumb JA, Sanchez DJ (1983) Susceptibility of five species of fish to Edwardsiella ictaluri. J Fish Dis 6:261-266

Pollard DR, Johnson WM, Lior H, Tyler SD, Rozee KR (1990) Detection of the aerolysin gene in Aeromonas hydrophila by polymerase chain reaction. J Clin Microbiol 28:2477-2481

Editorial responsibility: Carey Cunningham,

Aberdeen, Scotland, UK
Richtzenhain LJ, Cortez A, Heineman MB, Soares RM and 5 others (2002) A multiplex PCR for detection of Brucella spp. and Leptospira spp. DNA from aborted bovine fetuses. Vet Microbiol 87:139-147

Rosenfield SI, Jaykus LA (1999) A multiplex reverse transcription polymerase chain reaction method for detection of food-borne viruses. J Food Prot 62:1210-1214

Shieh HS (1980) Studies on the nutrition of a fish pathogen, Flexibacter columnaris. Microbios Lett 13:129-133

Shotts EB, Waltman WD (1990) A medium for selective isolation of Edwardsiella ictaluri. J Wildl Dis 26:214-218

Triyanto A, Wakabayashi H (1999) Genotypic diversity of strains of Flavobacterium columnare from diseased fish. Fish Pathol 34:65-71

Ullmann D, Krause G, Knabner D, Weber H, Beutin L (2005) Isolation and characterization of potentially human pathogenic, cytotoxin-producing Aeromonas strains from retail seafood in Berlin, Germany. J Vet Med Ser B 52:82-87

United States Department of Agriculture (2003) Part II: reference of food size catfish health and production practices in the United States. Publ. No N407.1103, United States Department of Agriculture, Animal and Plant Health Inspection Services, National Animal Health Monitoring System, Fort Collins, CO, p 58-59

Vantarakis A, Komininou G, Venieri D, Papapetropoulou M (2000) Development of a multiplex PCR for detection of Salmonella spp., and Shigella spp. in mussels. Lett Appl Microbiol 31:105-109

Wagner BA, Wise DJ, Khoo LH, Terhune JS (2002) The epidemiology of bacterial disease in food-size channel catfish. J Aquat Anim Health 14:263-272

Weisburg WG, Barns SM, Pelletier DA, Lane DJ (1991) 16S ribosomal DNA amplification for phylogenetic study. J Bacteriol 173:697-703

Welker TL, Shoemaker CA, Arias CR, Klesius PH (2005) Transmission and detection of Flavobacterium columnare in channel catfish Ictalurus punctatus. Dis Aquat Org 63: 129-138

Submitted: August 24, 2006; Accepted: November 29, 2006 Proofs received from author(s): March 9, 2007 